\title{
Relationships of Corporate Governance Mechanisms and Financial Performance in Islamic Banks: A Meta-Analysis
}

\author{
Yongqiang Li, Anona Armstrong and Andrew Clarke \\ Victoria University, Australia
}

\begin{abstract}
Relationships between corporate governance mechanisms and the financial performance of Islamic banks have been researched extensively in prior empirical research. However, the results are mixed, mainly due to the heterogeneity of the samples used for the empirical investigations. This paper reports the results of a meta-analysis of the existing literature on governance mechanisms from which a framework was developed to guide the constructions of governance indices. The results showed that Islamic banks banks tend to have better financial performance if there was (1) a higher proportion of independent directors on the board; (2) the Shari" ah Supervisory Board was large and consisted of top scholars; (3)numerous directors; (4) the CEO was chairman; (5) auditing was enforced and (6) ownership structure was dispersed, reducing shareholding of directors, foreigners and institutional investors, while increasing family and governments' shareholding. Managers' shareholding was insignificant.
\end{abstract}

\section{Keywords}

corporate governance, financial performance, meta-analysis, Islamic banks

\section{Introduction}

On September 15, 2008, Lehman Brothers Holdings Inc., the 4th largest investment bank in US, filed for Chapter 11 bankruptcy protection, marking the largest ever bankruptcy in the American history. It was followed by the massive exodus of most of its clients, drastic losses in its stock, and devaluation of its assets by credit rating agencies. The aftermaths of the 2008 US subprime mortgage crisis urged the banking sector to review their governance models. Rarick (2009) introduced the "Islamic system" as an optimal substitute to the existing capitalistic model to the Global Financial Crisis. However, without proper understanding of the role corporate governance play on the performance of Islamic banks themselves, how dare one suggest such quick remedy?

Corporate governance has already grown into an established and well studied subject being in

Copyright (C) 2014 Victoria University. This document has been published as part of the Journal of Business Systems, Governance and Ethics in both online and print formats. Educational and non-profit institutions are granted a nonexclusive licence to utilise this document in whole or in part for personal or classroom use without fee, provided that correct attribution and citation are made and this copyright statement is reproduced. Any other usage is academia as well as in practice (Clarke, 2004, Classens, 2006). Corporate governance is mainly concerned with control and decision making at the top of organisations and, in particular, corporate boards' roles, composition and accountability. Until now, corporate governance has mostly been dedicated to and concerned with traditional western corporations. Many studies have focused 
on large western banks with many thousands of employees, and that are publicly traded on the stock market with a free float of shares of shareholders with only a small proportion of equity held in the firm. There is only scarce evidence on corporate governance in the Islamic banking sector.

The dramatic growth of the Islamic banking sector around the world merits its significance in the financial market. Hence, the focus of this study was to summarise the evidence for, and determine the relationship between, corporate governance and financial performance of Islamic banks. This would also identify areas for future research as well as inform policy decision-making by Islamic banking regulators.

Thus, the research question is: What is the relationship between corporate governance mechanisms and financial performance of Islamic banks?

For Islamic Financial institutions, conflicts of interest are two-folded, meaning that they have to face the separation of ownership and control as well as the Shari"ah compliance on behalf of the regulators. Thus, this paper analyses both traditional corporate governance mechanisms applicable to Western banks and the Shari"ah Supervisory Board (SSB).

The rest of the paper proceeds as follows: Section 2 reviews the literature pertinent to corporate governance and financial performance of Islamic banks and develops the research hypotheses, covering six major corporate governance mechanisms, namely board independence, Shari"ah Supervisory Board (SSB), board size, CEO duality, ownership structure and auditing. Section 3 provides the methodological details of the meta-analysis. The results are reported in Section 4. Section 5 concludes with a summary and discussion of the research findings, acknowledges the limitation of this study, and identifies future research directions.

\section{LITERATURE REVIEW AND RESEARCH HYPOTHESES}

A literature search has identified a number of governance mechanisms pertinent to the financial performance of Islamic Banks, including board independence, Shari”ah Supervisory Board (SSB), board size, CEO duality, ownership structure and auditing (Chapra and Ahmed 2002). Thirteen research hypotheses concerning each corporate governance mechanism were drawn from the relevant literature reviewed below.

\subsection{Board independence}

Under Agency Theory, independent directors are more likely to be effective in monitoring the control of assets by the professional managers in that the independent directors are more likely to objectively question and evaluate the performance of both management and the firm (Kesner and Johnson 1990). Prior research suggests that there is an association between independent directors and stronger corporate governance, in the forms of reducing the likelihood of a firm paying greenmail and facing shareholder lawsuits, experiencing a negative market reaction to the announcement of a poison bill adoption, more appropriate design of CEO compensation policy, acting on behalf of stakeholders in order to secure higher premiums for tenders, making better acquisition decisions and promoting ethical financial reporting codes (de Villiers, Naiker, et al. 2011).

\section{H1: There is a positive relationship between board independence and financial performance.}

\subsection{Shari"ah Supervisory Board (SSB)}

The main distinction between Islamic banks and conventional banks lies in the requirement for the operations of Islamic banks to be in accordance with the Islamic Shari"ah. This requirement provides the foundation for the operation of Islamic banks to be guided by the principles and values laid down in Islam. Furthermore, it has been argued that the integrity of an Islamic bank would be undermined, and stakeholders would lose confidence, if its operation was found to be non-compliant to the Shari"ah (Alman 2012).

As the main objective of the establishment of an Islamic bank is the provision of financial activities that are Shari"ah compliant, the shareholders and stakeholders of an Islamic bank are expected to put pressure on the bank to accomplish this objective. The investment decision of the shareholders, for 
example, is deemed to be influenced by the assurance that the activities of the bank and the profit generated from them are Shari"ah compliant. In addition, institutional investors who usually hold a large stake in the shareholding of a corporation would exercise their voting power to decide on the policies and business operations that would provide a positive return on their investment while ensuring the ethical aspect of the Islamic banking operation remains intact. Meanwhile, to ensure that the credibility of the bank is preserved in accordance with the expectations of these shareholders, the board of directors would monitor the management and require the latter to report to them that the activities of the bank are Shari"ah compliant. These tasks are undertaken with the assistance of an external and independent Shari"ah board which comprises experts on Shari"ah and on fiqh almua"malat-related knowledge. The Shari"ah board advises the board of directors on the Shari"ah aspects of the Islamic banking operation and the latter carry out a Shari"ah compliance review of the bank. The conclusions drawn by the Shari"ah board based on the results of the Shari"ah compliance review are published in a Shari"ah report that is issued annually along with the financial statements of the bank.

The Shari"ah compliance review of an Islamic bank's activities is considered to be a crucial governance mechanism to ensure the credibility and viability of the financial institutions because of the requirement for Islamic banks to adhere to the Islamic Shari"ah principles. For this reason, many banks offering Islamic banking products and services have established a SSB whose membership and hierarchical position in the bank is deemed to stand no comparison to other types of supervisory boards.

The available literature presents a growing interest in the issue of the governance functions of the Shari"ah board in Islamic banks (Hassan 2012). According to Hassan (2012), in the Islamic Banking industry, the SSB mainly serves the following three functions: (i) at the macro level, SSB assumes regulatory authority; (ii) SSB at the micro level supervises the Shari"ah compliance of the Islamic banks; (iii) SSB is an useful source for business development; and (iv) SSB operates independently.

\section{H2: SSB is positively related to the financial performance of Islamic banks.}

\subsection{Board size}

Of all the corporate governance mechanisms, boards of directors and in particular board composition and board size have received much attention in the media and business community (Adams, Hermalin et al. 2008; Brown, Beekes et al. 2011; van Essen, Oosterhout et al. 2012). However, a confirmative answer for the relationship between board size and performance of small firms is yet to be established. Agency Theory argues for a smaller board in that it saves transaction costs associated with the group thinking problem and related unnecessary costs to reach consensus. While the Resource Dependency Theory claims that a larger board will not only provide the monitoring function of the boards but also enrich the Islamic bank's resource in the form of their collection of expertise and resources.

\section{H3: Board size is positively correlated with financial performance of Islamic banks.}

\subsection{CEO duality}

A dual role of CEO and chairman is a key characteristic of insider power and considered an indicator of weak corporate governance (Larcker et al. 2007, Yermack 1996). Most U.S. companies have traditionally appointed a single individual to the roles of both chairman of the board and CEO. This concentration of power can permit the CEO to effectively control information available to other board members and can impede effective monitoring (see Jensen, 1993). This duality was present in companies involved in fraud (e.g., Enron, Worldcom, and Global Crossing). As well, Beasley et al. (1999) found that the CEO was involved in $72 \%$ of the frauds which they examined. Several studies have examined the separation of CEO and chairman of the board, positing that agency problems are higher when the same person occupies the two positions. Using a sample of 452USA public firms between 1984 and 1991,Yermack (1996) showed that firms are more valuable when the CEO and the chairman of the board positions are occupied by different persons. Carpeto et al.(2005) found that the decision to split the roles of CEO and board chair is associated with positive and significant abnormal returns. Similarly, Larcker et al. (2007) concluded that the duality role of CEO and chairman is a key 
indicator of weak corporate governance. Therefore, the Cadbury Committee recommended separating the roles of the CEO and board chair to ensure a clear division of responsibilities at the head of the company (Al Manaseer, Al-Hindawi, et al. 2012).

\section{H4: CEO duality can improve the financial performance of Islamic banks.}

\subsection{Ownership structure}

According to Berle and Means (1932), the modern corporation is characterized by the separation of ownership from control. Recent work on separation of ownership and control has shown that ownership concentration levels have important implications for firm performance. The impact of ownership on firm performance is two-folded. On the one hand, the size of ownership stake and the incentive to monitor are positively correlated. Concentrated ownership can also provide better control of management (Jensen and Meckling 1976), which can benefit minority shareholders by improving the monitoring of managers (Shleifer and Vishn 1997). On the other hand, it can come with costs for minority shareholders as controlling owners might try to expropriate greater benefits from the firm (Grant and Kirchmaier 2004).

\section{H5: Concentrated ownership leads to better financial performance in Islamic banks.}

Ownership may exist in one of the following six forms, namely blockholding, director ownership, family ownership, foreign ownership, government ownership, institutional ownership, and management ownership (Abbas et al. 2009).

Blockholding, also called concentrated ownership, incurs the least agency cost given that the owner did not trade the control of assets with management (Jensen and Meckling 1976). Hence

\section{H6: Blockholding adds value to the financial performance of Islamic banks.}

Even though share ownership by directors may provide incentives for directors to exercise diligent monitoring, the massive shareholding by directors may conflict with the interests of the other shareholders.

\section{H7: Director ownership has a negative impact on the financial performance of Islamic banks.}

Family ownership is expected to be positively related to firm performance since it helps reduce the agency costs of separation of ownership and control. In this type of firms, the interest of the managers is naturally aligned with those of the owners since the owners are also the managers who could bring benefits to the firms (Abbas et al. 2009).

\section{H8: Higher family ownership is associated with higher financial performance in Islamic banks.}

Kho and Stulz (1997) find no evidence that the foreign investors outperform the local investor in Japan. Moreover De Young and Nolle (1996) and Elyasiani and Mehdian (1997) found that foreignowned banks were not as profitable as domestically owned banks. De Young and Nolle (1996) reasoned out that foreign owned banks were less profitable because of their reliance on purchased funds. Elyasiani and Mehdian (1997) concluded that foreign-owned banks tend to be less costefficient than domestic banks, which in turn affects profitability.

H9: Foreign ownership has negative relationship with financial performance of Islamic banks.

Ab Razak et al. (2008) argued that the government ownership contribute positively to performance, mostly due to the investments made by government through their various government related companies. It is believe that a government will take action to avoid underperforms of their investment in companies in which they invest. Based on these arguments the study hypothesizes that:

H10: Higher the government ownership has positive effect on financial performance of Islamic banks.

The emergence of institutional investors (owners) as active owners has resulted in studies investigating their role as active monitoring agents for enhancing firm performance. It is argued that only large shareholders such as the institutional investors can achieve sufficient benefits to have the incentive to monitor managers and members of the board (Shleifer and Vishny 1986). However, the 
assignment of representatives - agents of the institutions would incur extra agency cost and hence making the institutions 'inactive'.

H11: Institutional investors have a positive impact on financial performance of Islamic banks.

Management ownership may align the interest of the managers and shareholders and hence improve the financial performance (van Essen and Osterhout 2008).

H12: Management ownership is positively associated with financial performance of Islamic banks.

\subsection{Auditing}

Auditing facilitates the Shari'ah compliance and encourages the Islamic banks to adopt appropriate financial reporting codes and good practice (Brown et al. 2011).

H13: Auditing is positively correlated with financial performance of Islamic banks.

Table 1 Definition of the variables

\begin{tabular}{l|l}
\hline \multicolumn{1}{c|}{ Variable } & \multicolumn{1}{c}{ Definition } \\
\hline Board size & Number of board of directors \\
\hline Financial performance & ROA, ROI, Tobin's Q \\
\hline Board independence & Percentage of independent directors on the board \\
\hline $\begin{array}{l}\text { Shari'ah Supervisory } \\
\text { Ranrd }\end{array}$ & The SSB size, percentage of SSB members on top 20 ranking \\
\hline CEO duality & Whether the CEO is also chairman. \\
\hline Ownership structure & The percentage of shares held by the largest five shareholders. \\
\hline Auditing & Whether the firm has been externally audited. \\
\hline Director ownership & The proportion of shares held by the directors. \\
\hline Family ownership & Whether the largest shareholder is family. \\
\hline Foreign ownership & Whether foreigner own shares. \\
\hline Government ownership & Whether the largest shareholder is the government. \\
\hline Institutional ownership & Whether the largest shareholder is the institution. \\
\hline Blockholding & Whether the shares are held by the largest three shareholders. \\
\hline
\end{tabular}




\section{METHODOLOGY, DATA AND RESULTS}

The methodology included a meta-analysis of existing research to identify previous research and testing of hypotheses based on the evidence derived from these previous studies.

\section{Meta-analysis}

To address the theoretical debates and to consolidate existing knowledge, this study systematically reviewed all the empirical evidence obtainable from a number of database sources specified below. Literature which met the criteria was quantified to test the statistical hypothesis using a meta-analysis approach.

\section{Sampling and coding}

Five complementary strategies were used to identify the population of studies on corporate governance and financial performance of Islamic Banks, (Li. et al. 2013). First, six databases were searched using key terms, "board", "board of directors", "board size", "board independence", "Shari"ah Supervisory Board (SSB)", "CEO duality", "ownership structure", "blockholding", "director ownership", "family ownership", "foreign ownership", "government ownership", "institutional ownership", "management ownership", "auditing", "board characteristics", "governance", and "corporate governance", married with "Islamic Banks", "Islamic Financial Institutions". The databases include (1) JSTOR; (2) ProQuest ; (3) ABI/INFORM Global; (4) EconLit; (5) SSRN; (6) Google Scholar.

Second, a search was conducted of the most relevant journals suggested by the Australian Research Council's ERA Ranking in the fields of accounting, economics, finance and management. Third, after collecting an initial set of studies, a "snow-balling" technique cross-checked the reference that cited the original journals using Scopus and Google Scholar. An initial sample of 41 literature sources yielded 39 published or unpublished articles and 2 recent $\mathrm{PhD}$ theses.

Given that our research focus is on the correlation of board size and firm performance, Each article was then checked against the six criteria, specified as follows:

(1) The paper is not an earlier version of another paper included in our sample;

(2) The paper is an empirical study that includes either a regression or a correlation analysis, as long as the impact size is estimable;

(3) The sample used in the empirical research must be a cohort of Islamic banks, or have an Islamic cohort, whose effect size are reported separately and can be obtained. Thus, our sample includes articles on Islamic banks as well as Islamic financial institutions;

(4) Corporate governance mechanisms must be a separate variable and must be identifiable;

(5) The paper only focused on using financial performance related measures as the dependent variable.

(6) The full text of the article must be obtainable.

Applying the above six criteria, resulted in twelve articles (Table 2).

\section{Coding and analysis}

Two main types of data are encountered in the sample: correlation coefficients with sample size, and regression results (either a t-statistics or p-value) with sample size.

The data were analysed using a commercial coding package, Comprehensive Meta Analysis . The build-in functions and consistency in correcting estimation errors exempt the coding from human calculation errors. The Hedges and Olkin (1985) (HOMA) procedure is computed in STATA12SE environment. Observations with missing values on either the corporate governance variable or financial performance variable are dropped. 


\section{HOMA procedure}

Pearson product-moment correlation coefficient $r$ and partial correlation coefficient rxy, $\mathrm{z}$ are commonly used in meta-analysis, given that they are scale-free, can be easily interpreted and computed, eg. using the HOMA procedure in STATA. Only studies in which performance variables are dependent variables are partial coefficients calculated. In our study, when multiple measures of firm performance are provided, all the available measurements from the sample were included in the study. In order to account for the differences in precision across effect sizes and variability in the population, the HOMA procedure, which treats the inverse variance weight was the optimal measure of precision for a given effect size. These weights will help to produce appropriate estimates for the meta-analytic mean effect size (van Essen and Oosterhout et al. 2012). The HOMA procedure will be used to estimate Hypothesis 1-12.

A mapping between the selected literature and effect sizes of corporate governance mechanisms is shown in Table 3. 


\begin{tabular}{|c|c|c|c|c|c|c|}
\hline z & $\widehat{\sim}$ & g & f & ते & $\tilde{d}$ & $\infty$ \\
\hline 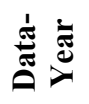 & $\stackrel{\infty}{\stackrel{i}{i}}$ & 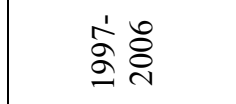 & $\begin{array}{l}\dot{d} \circ \\
\stackrel{2}{\sigma}\end{array}$ & & 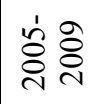 & $\begin{array}{l}\dot{1} \% \\
\text { ळे } \\
\sigma\end{array}$ \\
\hline ن̈ & 己 & 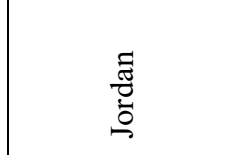 & 尝 & ర己 & $\begin{array}{l}\overline{0} \\
\frac{0}{0} \\
0\end{array}$ & 売 \\
\hline 丞 & 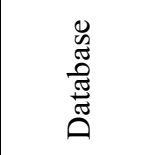 & 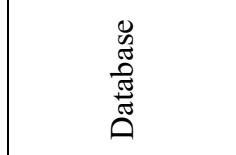 & 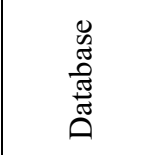 & 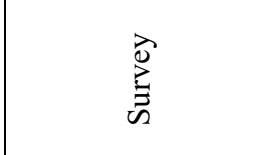 & $\begin{array}{l}0 \\
0 \\
\tilde{\Xi} \\
\tilde{\Xi} \\
\tilde{\Xi} \\
0\end{array}$ & 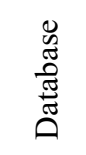 \\
\hline 岕 & - & 0 & 0 & - & 0 & 0 \\
\hline 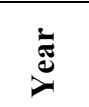 & $\overline{\vec{\sim}}$ & $\stackrel{\sim}{\stackrel{\sim}{*}}$ & $\stackrel{m}{\stackrel{n}{i}}$ & ڤ్ & $\stackrel{\sim}{\stackrel{i}{*}}$ & $\begin{array}{l}\infty \\
\stackrel{\sim}{े}\end{array}$ \\
\hline 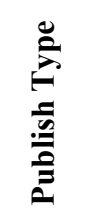 & 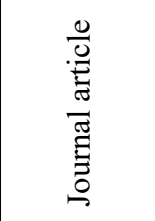 & 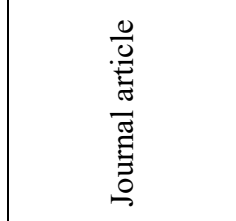 & 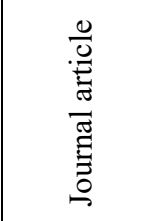 & 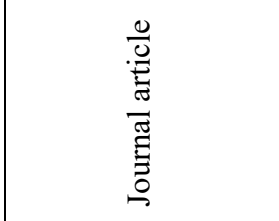 & 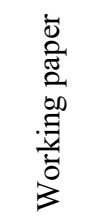 & 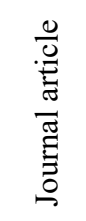 \\
\hline 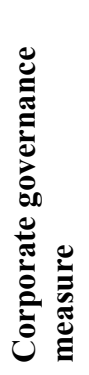 & 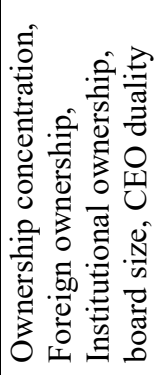 & 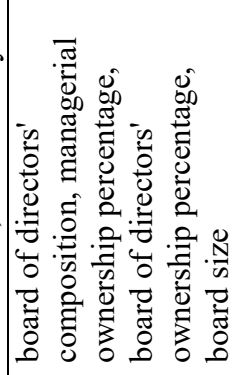 & 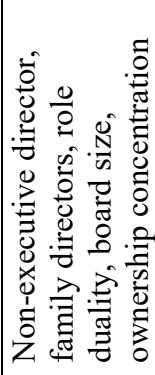 & 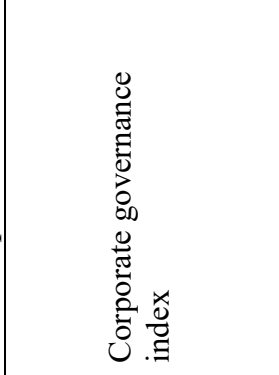 & 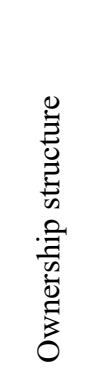 & 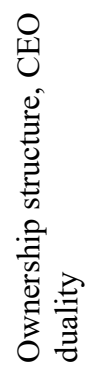 \\
\hline 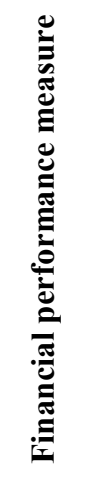 & 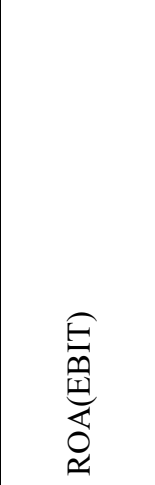 & 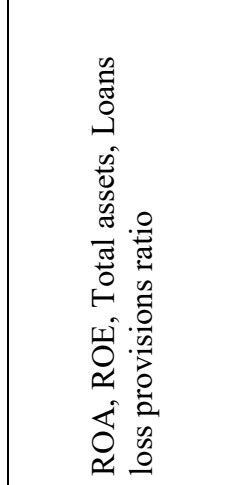 & $\begin{array}{l}0 \\
-\infty \\
: \nexists \\
0 \\
0 \\
0 \\
0 \\
\approx\end{array}$ & 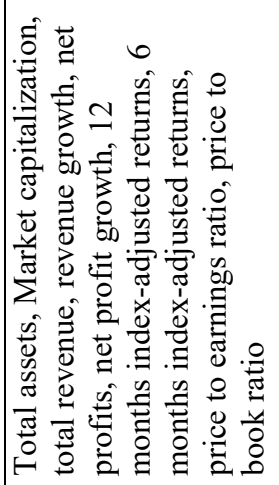 & 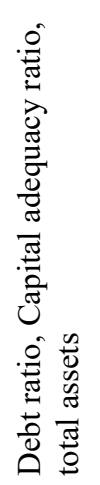 & $\begin{array}{l}\overrightarrow{0} \\
0 \\
\overrightarrow{0} \\
\overrightarrow{0} \\
\ddot{z}\end{array}$ \\
\hline & 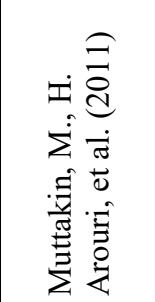 & 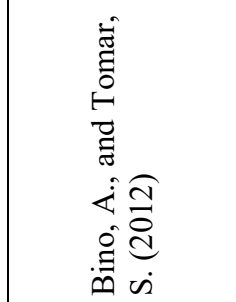 & 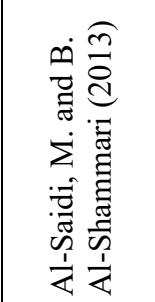 & 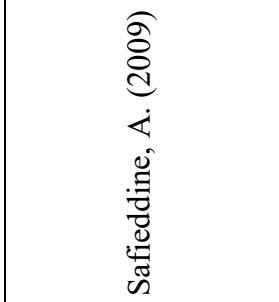 & 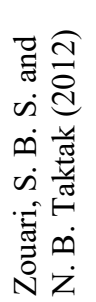 & 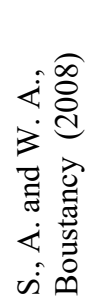 \\
\hline
\end{tabular}




\begin{tabular}{|c|c|c|c|c|c|c|}
\hline z & $\bar{n}$ & 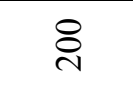 & $\stackrel{\infty}{\circ}$ & กี & ల & $\mathscr{n}$ \\
\hline 离 & 㝘完 & 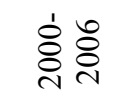 & $\begin{array}{l}\text { dेंn } \\
\text { ळे }\end{array}$ & $\begin{array}{l}\dot{1} 0 \\
\stackrel{2}{\sigma} \\
\stackrel{\sigma}{\sigma}\end{array}$ & & 悹宫 \\
\hline تُ & $\begin{array}{l}\overline{0} \\
\stackrel{0}{0} \\
0\end{array}$ & $\frac{. \frac{\pi}{20}}{\frac{\sqrt{0}}{2}}$ & 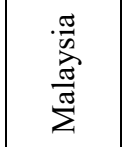 & $\stackrel{\coprod}{S}$ & 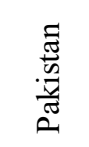 & 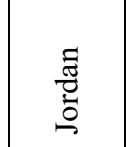 \\
\hline 气̃ & 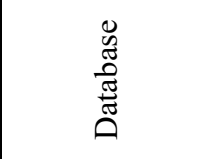 & 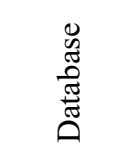 & 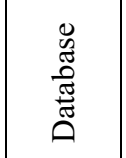 & $\begin{array}{l}0 \\
0 \\
0 \\
\tilde{\pi} \\
\tilde{\pi} \\
0\end{array}$ & 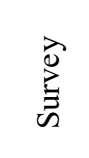 & 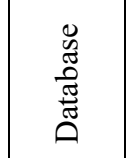 \\
\hline 离 & 0 & 0 & 0 & 0 & 0 & 0 \\
\hline$\stackrel{\varpi}{\varpi}$ & 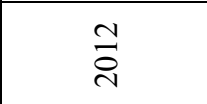 & ठे & $\overrightarrow{\text { i }}$ & $\stackrel{m}{i}$ & $\stackrel{m}{i}$ & 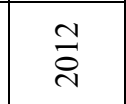 \\
\hline 离 & 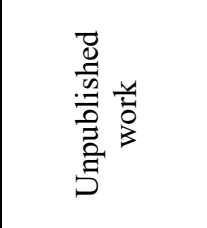 & 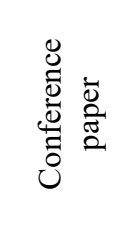 & 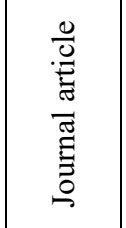 & 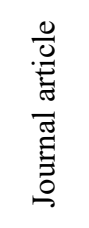 & 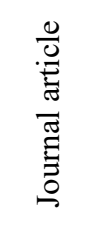 & 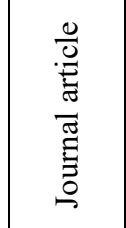 \\
\hline 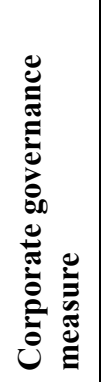 & 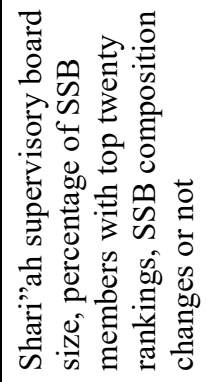 & 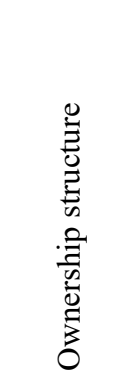 & 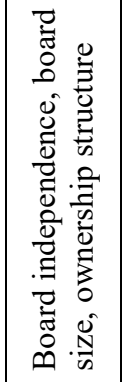 & 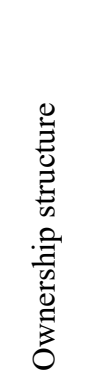 & 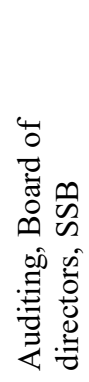 & 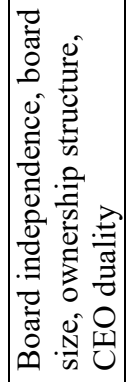 \\
\hline 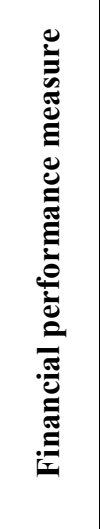 & 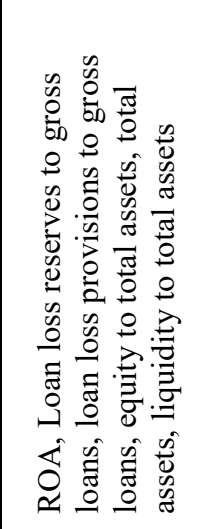 & 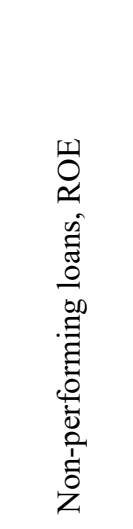 & 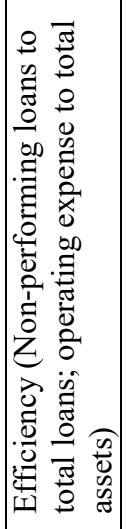 & 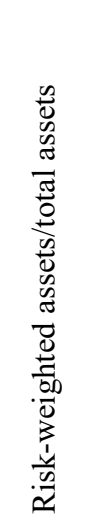 & 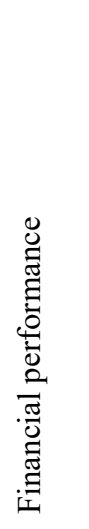 & 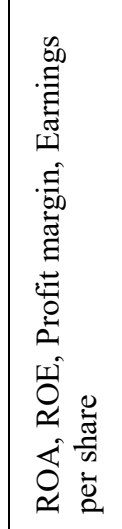 \\
\hline & 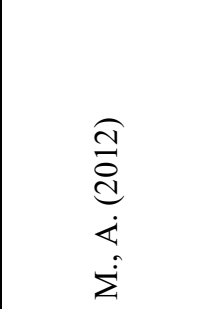 & 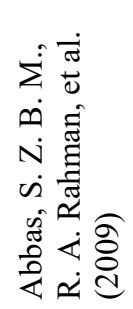 & 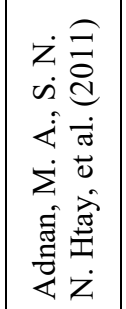 & 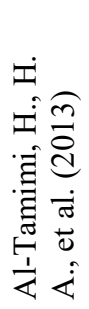 & 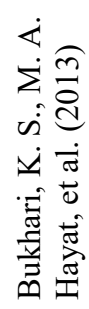 & 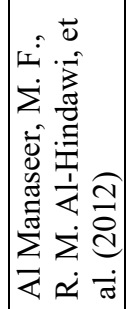 \\
\hline
\end{tabular}




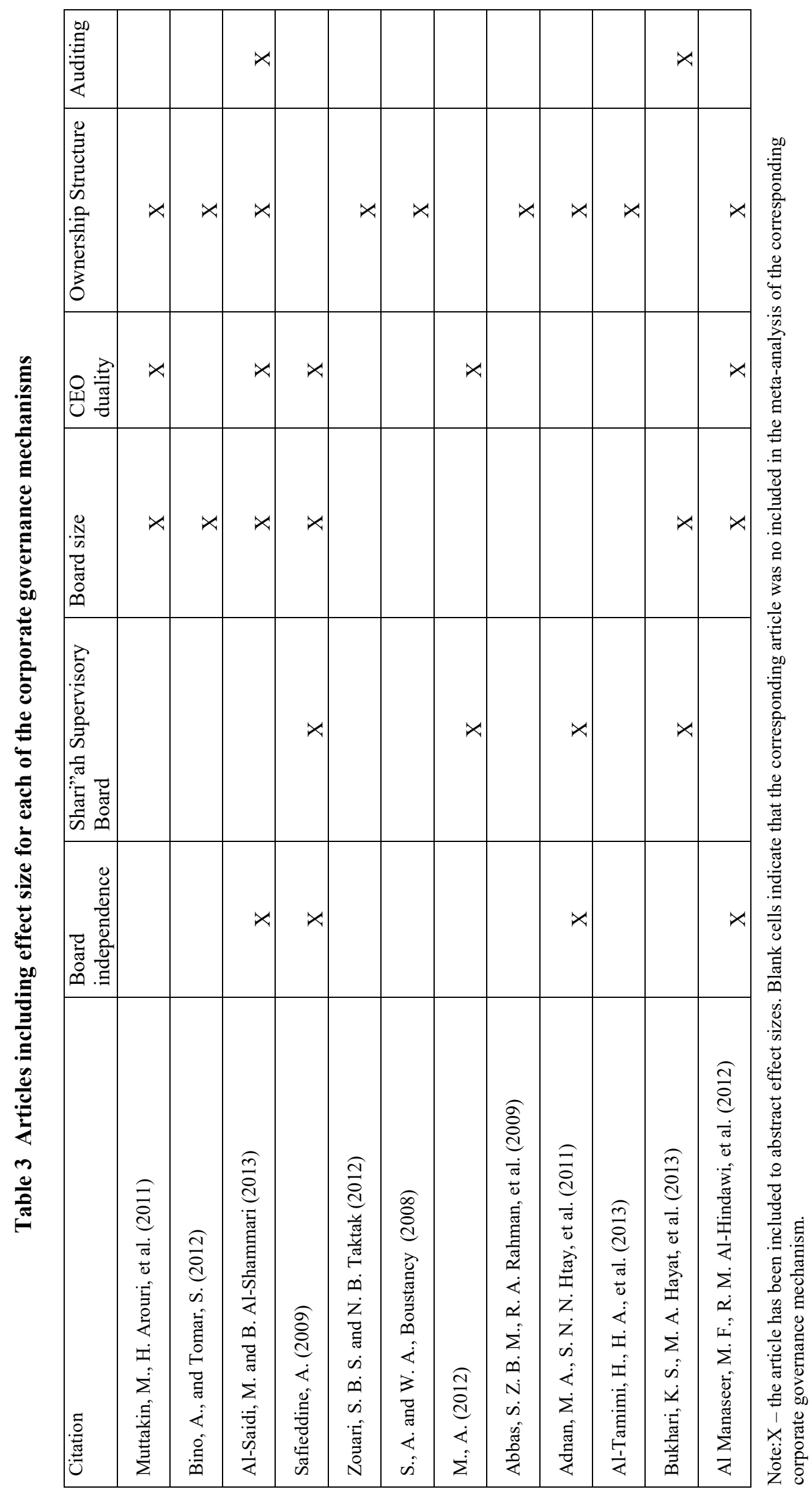




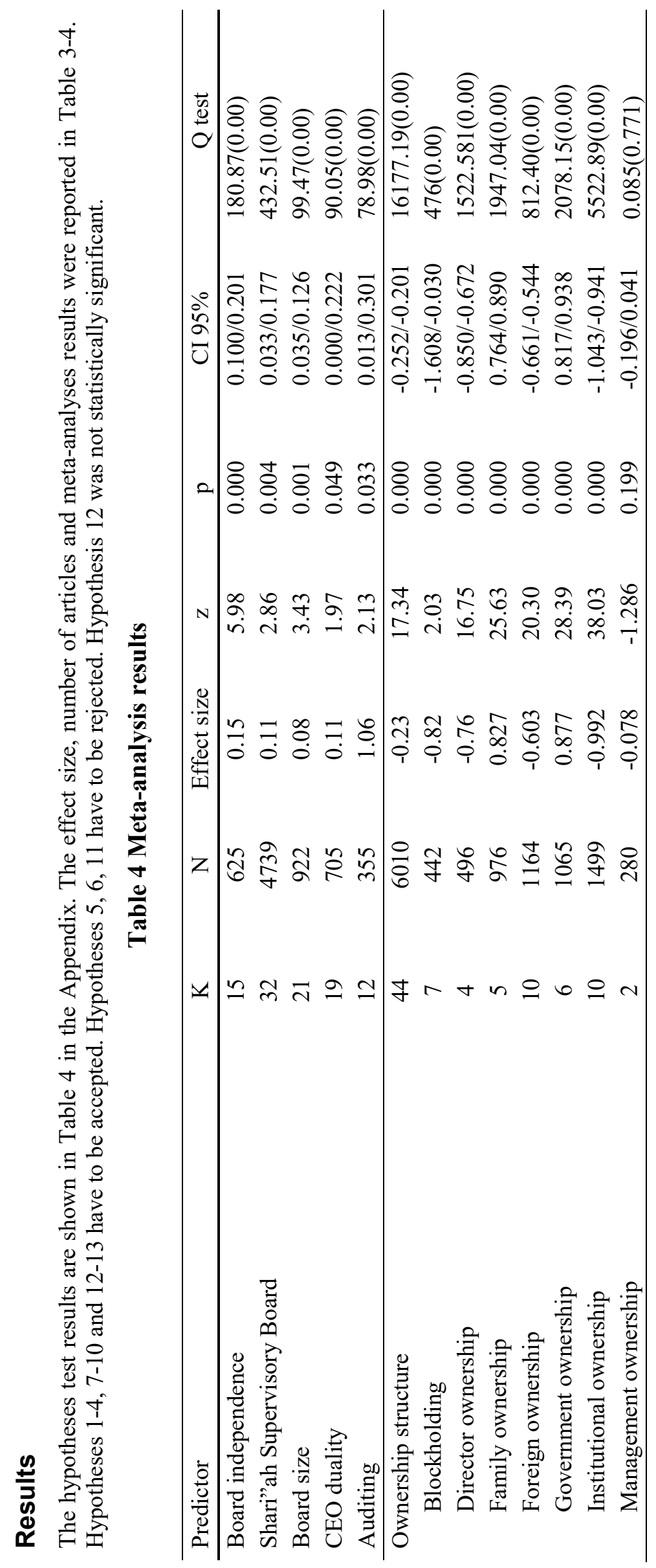




\section{FINDINGS AND DISCUSSION}

The meta-analyses shows that Islamic banks tends to have better financial performance if (1) a higher proportion of independent directors on the board; (2) Shari"ah Supervisory Board is larger and is consist of top scholars; (3) more directors sitting on the board; (4) CEO is also the chairman of the board of directors; (5) internal and external auditing are enforced and (6) ownership structure were more dispersed, directors' shareholding were reduced, foreigners shareholding were reduced, institutional investors' shareholding were reduced, while family and governments' shareholding were increased. (7) Managers' shareholding was insignificant.

The summary of the statistical hypotheses and the test results are listed in Table 5.

Table 5 Comparison of statistical hypothesis and test results

\begin{tabular}{|c|l|c|c|}
\hline Hypothesis No. & Corporate governance mechanism & Hypothesized sign & Test result \\
\hline 1 & Board independence & + & $0.15^{* * *}$ \\
\hline 2 & Shari”ah Supervisory Board & + & $0.11^{* * *}$ \\
\hline 3 & Board size & + & $0.08^{* * *}$ \\
\hline 4 & CEO duality & + & $0.11^{*}$ \\
\hline 5 & Ownership structure & + & $-0.23^{* * *}$ \\
\hline 6 & Blockholding /Concentrated ownership & - & $-0.82^{* * *}$ \\
\hline 7 & Director ownership & + & $-0.76^{* * *}$ \\
\hline 8 & Family ownership & - & $0.827^{* * *}$ \\
\hline 9 & Foreign ownership & + & $-0.603^{* * *}$ \\
\hline 10 & Government ownership & + & $-0.877^{* * *}$ \\
\hline 11 & Institutional ownership & + & -0.078 \\
\hline 12 & Management ownership & + & $1.06^{*}$ \\
\hline 13 & Auditing & & + \\
\hline
\end{tabular}

Four of the thirteen statistical hypotheses (highlighted in Table 5), namely ownership structure, blockholding, institutional ownership and management ownership contradict our hypotheses. The synthesise of the previous literature shows that a dispersed ownership structure, rather than a concentrated one, regardless of the blockholding of family, institutions, government, foreigners, managers, directors, is favourable for financial performance of Islamic banks, which is reconfirmed by the results on blockholding. The meta-analysis results indicate that less institutional ownership results in better financial performance, which is contradictory to the widely accepted evidence in the research into conventional banks. The role institutional ownership plays merits further investigation. Management ownership is not significant.

\section{Limitations of the study}

As with every meta-analysis, this study is subject to limitations. Some limitations are inherent in the primary studies. For example, all studies included in our meta-analysis exclusively examine surviving firms, and none corrected for survival bias. In addition, attempting to trace the validity and credibility of the data as well as analytical strategies used in the original studies is a 'mission impossible'.

Moreover, the systematic review of the major database also flags a number of concerns for the researchers, listed as follows:

i. Corporate governance in Islamic banks suffers from having a shadowy existence in business and economics. Articles reviewed here are mostly published in niche journals. Over the past decade, Islamic banks have come to the fore and academic research has increasingly attempted to understand how those banks differ from their conventional counterparts. However, most efforts have been devoted to comparisons between the Islamic banking and Conventional banking sectors, while studis 
purely focusing on Islamic banks rarely appear in top journals in Economics, Finance and Management disciplines.

ii. Lack of a systematic solid evidence base left the Islamic bank related corporate governance research in an impasse of conceptualisation. Only two studies out of twelve in the review have a sample size larger than 200, albeit some are still using logit and probit models to test statistical hypothesis. The robustness of the empirical results has to be cross-validated in order to obtain a stable and parsimonious model.

iii. The data on corporate governance of Islamic banks is at a dearth. It will be a luxury for researchers if future endeavours should attempt to develop an objective and reliable database with corporate governance data for Islamic banks worldwide.

iv. Collaboration and communication among Islamic bank researchers and practitioners should be reinforced. The reviewer articles flagged the issues that there are overlaps in the research topic but the story may conflict and not be comparable because of the use of different data sources.

Future research efforts can be devoted to the establishment of an Islamic corporate governance database, a singular focus on the analysis of the impact of corporate governance on financial performance of the Islamic banking sector, and an in-depth investigation of the role institutional investors and management ownership play in the governance of Islamic banks.

\section{Reference}

Abbas, S. Z. B. M., R. A. Rahman, et al. (2009). Ultimate ownership and performance of islamic financial institutions in malaysia. FMA International First Asian Conference, 1-25.

Adnan, M. A., Htay, S. N. N., Rashid, A., Majdi, H., Meera, M., \& Kameel, A. (2011). A panel data analysis on the relationship between corporate governance and bank efficiency. Journal of Accounting, Finance and Economics, 1(1), 1-15.

Al Manaseer, M. F., R. M. Al-Hindawi, et al. (2012). "The Impact of Corporate Governance on the Al-Saidi, M., \& Al-Shammari, B. (2013). Board composition and bank performance in Kuwait: an empirical study. Managerial Auditing Journal, 28(6), 472-494.

Al-Tamimi, H., H. A., et al. (2013). "The Effects of Ownership Structure and Competition on RiskTaking Behavior: Evidence from UAE Conventional and Islamic Banks." The International Journal of Business and Finance Research 7(2): 115-124.

Alman, M.(2012). Shari"ah supervisory board composition effects on islamic banks' risk-taking behavior. Bamberg University Working Paper series, 1-43.

Arouri, H., Hossain, M., \& Muttakin, M. B. (2011). Ownership Structure, Corporate Governance and Bank Performance: Evidence from GCC Countries. Corporate Ownership and Control, 8, 365370.

Bino, A., \& Tomar, S. (2012). Corporate governance and bank performance: evidence from Jordanian banking industry. Jordan Journal of Business Administration, 8(2), 123-141.

Boustancy S.A. and Bounstancy W. A. (2008). "Corporate governance, ownership structure and bank performance: evidence from the middle east and north Africa." ASAC, 1-26.

Chapra, M. U. and H. Ahmed (2002). "Corporate Governance in Islamic Financial Institutions." Occasional Paper No. 6, Jeddah, IRTI/IDB, 1-170.

Clarke, T. 2004. Theories of Corporate Governance. New York, Routledge.

Claessens, S. (2006)" Coproate Governance and Development". The World Bank Research Observer, Vol. 21,(1), 91-22.

de Villiers, C., V. Naiker, et al. (2011). "The effect of board characteristics on firm environmental performance." Journal of Management 37(6), 1636-1663. 
Harbord, R. M. and J. P. T. Higgins (2008). "Meta-regression in Stata." Stata J 8(4), 493-529.

Hassan, A. F. S. (2012). An empirical investigation into the role, independence and effectiveness of Shari'ah boards in the Malaysian Islamic banking industry (Doctoral dissertation, Section of Cardiff Business School, Cardiff University).

Hedges, L. V. and I. Olkin (1985). Statistical Methods for Meta-analysis. Orlando, FL, Academic Press.

Hillman, A. J., M. C. Withers, et al. (2009). "Resource dependence theory: A review." Journal of Management 35(6), 1404-1427.

Kesner, I. F. and R. B. Johnson (1990). "An investigation of the relationship between board composition and stockholder suits." Strategic Management Journal 11(4), 327-336.

Kobeissi, S., M. A. Hayat, A., Faareha (2013) An evaluation of corporate governance practices of Islamic banks versus Islamic bank windows of conventional banks: A case of Pakistan, Management Research Review, Vol. 36 (4), 400 - 416.

Rammal, H. G. (2012). Corporate governance in the Islamic banking system in Pakistan: the role of the Shari"ah supervisory boards. $\mathrm{PhD}$, University of Adelaide.

Rarick, C. A. (2009). "Islamic Finance: An Alternative in the Global Financial Market?" Available at SSRN 1332793.

Safieddine, A. (2009). "Islamic financial institutions and corporate governance: New insights for agency theory." Corporate Governance: An International Review 17(2), 142-158.

van Essen, M., van Oosterhout, J. H., \& Carney, M. (2012). Corporate boards and the performance of Asian firms: A meta-analysis. Asia Pacific Journal of Management, 29(4), 873-905.

Heugens, P. P., van Essen, M., \& van Oosterhout, J. H. (2009). Meta-analyzing ownership concentration and firm performance in Asia: Towards a more fine-grained understanding. Asia Pacific Journal of Management, 26(3), 481-512.

Zouari, S. B. S. and N. B. Taktak (2014). Ownership structure and financial performance in Islamic banks: Does bank ownership matter?, International Journal of Islamic and Middle Eastern Finance and Management, 7(2),146 - 160. 